\title{
Love, Medicine and Miracles
}

\author{
A.B.R. THOMSON, MD, PHD, FRCPC, FACP
}

A WERAGE HEIGHT, MIDDLE-AGED, BALD, EVEN A LITTLE HOMEly, he walks to the stage with a bounce that cries out 'I'm alive'. He begins to speak, filling the room with a mysticism, a mystique, an inspiration, his own personal miracle. Some humour, some sadness, some practical suggestions for we as physicians now, and as ourselves patients in the future may not cope as well with our patients' need for compassion and care in the mystery of transferring science to souls.

His book 'Love, Medicine and Miracles' was brought to my attention by Dr Ghislain Devroede, for which I am very grateful. Perhaps I would never have read this book had the author not been a physician. Perhaps you will disagree with his perspective, his methods, or even his conclusions. But to consider, to question, to challenge and to disagree, these are all part of a spectrum of personal change, which becomes the means by which we as doctors and, therefore, teachers begin the process of achieving the evolution which our healthcare system so badly needs, even a personal evolution.

How often have we reflected on the fact that patients treat physicians differently today than in the years gone by? But have we ourselves, the members of our profession, also possibly changed? Are we teaching our young physicians so much science that the art is lost? The art of listening, empathizing, touching, and knowing - not necessarily just knowing the results of the latest clinical trial (of course that is important,

This article was inspired by Bernie S. Siegel's book 'Love, Medicine and Miracles', published by Harper and Row. Inc, New York, 1989

Correspondence and reprints: Dr A.B.R. Thomson, 519 Robert Newton Research Building, University of Alberta, Edmonton, Alberta T6G 2C2 but is it enough?) but also to understand the patient's hopes, their dreams, their motivation. And how can we dare hope to acquire this? It is much more than a careful social history, although do our interns and residents really believe us when we say that these things are important? We ourselves need to become the vehicles by which the profession and it's teaching arms - the universities and the Royal College - become instruments once again in recognizing the importance of the human soul - by music, dance, poetry and great literature.

Take a look at the program of the next Royal College meeting. Days and days and days and days packed with hours and hours and hours of lectures and papers. But have these great bodies of learning ever asked each and every one of us what we enjoy the most at these meetings? For me, it is seeing old friends and colleagues, visiting the local art gallery, and maybe, just maybe, catching rush hour tickets to the symphony or theatre or even a hockey night in Canada. But do we ever tell our students just how important are the Arts? As curriculum committees cut more and more from the burden of the medical student, and less and less is required - such as the need for the students being citizens of the world - then we become responsible for part of this dehumanization of medicine. And what is Siegel's perspective?

In his book, 'Bernie', as he would ask to be known, suggests a means to the end of better medicine. Communication between researcher and clinician must occur, and then perhaps the new field of psychoneuralimmunology will help us to proceed in a direction linking consciousness and feelings. We must revise physician education and create caring, compassionate physicians, not technicians. As suggested in the 
forward by the author, "The temptation is that we use our expertise to keep a safe distance from that which really matters and forget that in the long run cure without care is more harmful than helpful". We need to create a healing team with positive, hopeful interactions. Some doctors do not consider how a patient's attitude towards life shapes that life's quantity and quality. "The fact that the mind rules the body is, in spite of its neglect by biology and medicine, the most fundamental fact that we know about the process of life" (Franz Alexander, MD).

Sir William Osler, the brilliant Canadian physician and medical historian, said that the outcome of tuberculosis had more to do with what went on in the patient's mind than with what went on in his lungs. He was echoing Hippocrates, who suggested that he would rather know what sort of person has a disease than what sort of disease a person has. Siegel hypothesizes that the fundamental problem most patients face is the inability to love themselves, having been unloved by others during some crucial part of their lives. This period is almost always childhood, when our relationships with our parents establish our characteristic ways of reacting to stress. Can patients change their attitudes? Can we as physicians change ours? We must remove the word 'impossible' from our vocabulary. As David Ben-Gurion once observed in another context: "Anyone who doesn't believe in miracles is not a realist". We, the physicians, must become the privileged listener. Perhaps we need to consider that death is not necessarily a failure and that we should be able to do more to help a person let go and end life easily when the value of each day is gone (of course, Siegel is talking about natural means of letting go). How can we say we are prolonging life when a person has become no more than a valve between the intravenous fluids going in and the urine coming out?

\section{EXCEPTIONAL CANCER PATIENT}

From his extensive experience with the exceptional cancer patient - ECaP', Siegel encourages us to teach each other, to know that happiness is an "inside job", but "in the face of uncertainty, there is nothing wrong with hope" (1). We need to teach patients how to live - teaching not from a pedestal but rather with the knowledge that we teach what we want to learn. Physicians must educate and at the same time learn from their patients. "Medicine is not only a science, but also the art of letting our individuality interact with the individuality of the patient" (Albert Schweitzer). The relationship between patient and physician may become a healing partnership; healing is a creative act, calling for all of the hard work and dedication needed for other forms of creativity.

We must help patients achieve peace of mind. Help comes about largely as a result of the patient's confidence and trust in the healer. This bond is forged in many ways. Certain essentials - compassion, acceptance, availability, a willingness to provide information - are obvious. A sense of humour is an enormous asset. Hospital personnel must realize that people aren 't 'living' or 'dying', they are either alive or dead. The physician must remember that it's the patient who must make the decision, and then live with it. We as physicians have the right to tell patients "If I had your illness I wouldn't choose your plan of treatment, because I don't think you have the best chance of being successful with it, but I will continue to keep a relationship with you, and if you wish, help in any way that I can". Our job is simply to accept patients and try to help them with all our skills and knowledge.

Unfortunately, this may be difficult for us to accept because in medical school we learn all about disease, but we learn little about what disease means to the person who has it. Equally, we learn little about ourselves. Disease is what is seen by the doctor, but an illness is a patient's objective experience of the same sickness. The two may be different, but it is important to ask patients what they think caused the problem, what threats and losses it represents to them and how they believe it should be treated. Doing what restores hope is beneficial. This instills in the patient a high level of motivation and such patients will often listen to the physician's advice and act on it.

\section{MECHANICS OR CAREGIVERS?}

Essential to a doctor's prime goal is the relief of suffering, We must caution ourselves that technological specialization is driving out the "exquisite regard for human needs". Have we become medical mechanics or caregivers? The denial of empathy benefits no one. This expanded outlook will help us as physicians to inspire hope, to give with the heart as well as with the head and hands, to keep ego in the background and to share major decisions with the patient.

Contentment used to be considered a prerequisite for health. As reflected upon by Hans Selye, the way we react to stress appears to be more important than the stress itself. Stress comes mainly from the patient's interpretation of events. In 'The Will to Live', Hutschencker wrote "Depression is a partial surrender to death, and it seems that cancer is despair experienced at the cellular level" (2). For those of us educated in the school of the 'Holy Trinity' of immunology, enzyme sequency and genetic engineering, this may seem like hogwash. But remember, ladies and gentlemen, that basic scientists do not care for the patient. This is our privilege. This is the perspective which we bring to medical science. Today, the basic scientist must help to solve these human problems, not to direct souls and minds of a future generation of physicians clothed in a tattered remnant of molecules rather than compassion and caring.

Within each of us is a spark. Call it the divine spark if you will, but it is there and can light the way to health. There are no incurable diseases, only incurable people! Let us learn to rekindle that spark in our patients, allowing them to participate in decisions, and to become actively involved in the process of living, of loving and of laughter. Perhaps some of us would not go so far as to completely agree with Siegel's four fundamental questions: "Do you want to live to be 100? What happened to you in the year before your illness? What does the illness mean to you? Why did you need the illness?" We may feel shy and self-conscious about the perspective of using dreams and drawings to receive messages from the patient's unconscious. Perhaps not all of us are ready to hear the mes- 
sage of a practising surgeon in New Haven, a teacher at Yale University. But certainly we would agree with Siegel that it is the doctor's duty to try to forge a bond of trust by learning and accepting the patient's beliefs, conscious and unconscious. We need to learn to love ourselves, to give rather than to get, in a sense of altruism which is based on unconditional love, rather than anticipated praise or other reward. This only serves to reinforce a genuine self-esteem that enables people to care for themselves effectively. Both giver and receiver are rewarded by the act of love itself.

Siegel speaks of spirituality rather than religion, when he seeks to use what is positive in each patient's beliefs. Patients need to deal with fears and long standing resentments or conflicts, the "unfinished business", as Elizabeth Kubler-Ross calls it. This comes about through the two linked opposites of selflove and love for others, of assertiveness and forgiveness. The ability to see something good in adversity is perhaps the central need of patients. As Viktor Frankl has written: "To live is to suffer; to survive is to find meaning in the suffering"(3). Spirituality, unconditional love and the ability to see that pain and problems are opportunities for growth and redirection - Siegel suggests that these things allow us to make the best of the time we have. In so doing we give the best of what we have as physicians.

\section{REFERENCES AND SUGGESTED READING}

1. Simonton OC, Matthews-Simonton S, Creighton J. In: Torcher JP, ed. Getting Well Again. New York: Bantam, 1980.

2. Hutschnecker A. The Will to Live. New York: Cornerstone Library, 1951.

3. Frankl V. Man's Search for Meaning. New York: Pocket Books, $1959,1980$.

4. Kubler-Ross E. On Death and Dying. New York: Macmillan, 1969

5. Kubler-Ross E. Death: The Final Stage of Growth. Englewood Cliffs, NJ: Prentice-Hall, 1975.

6. Kubler-Ross E. To Live Until We Say Goodbye. Englewood Cliffs, NI: Prentice-Hall, 1978. 


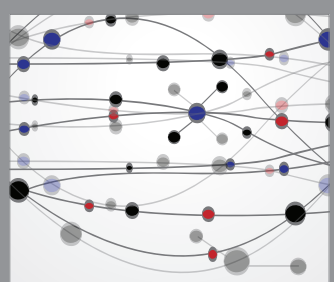

The Scientific World Journal
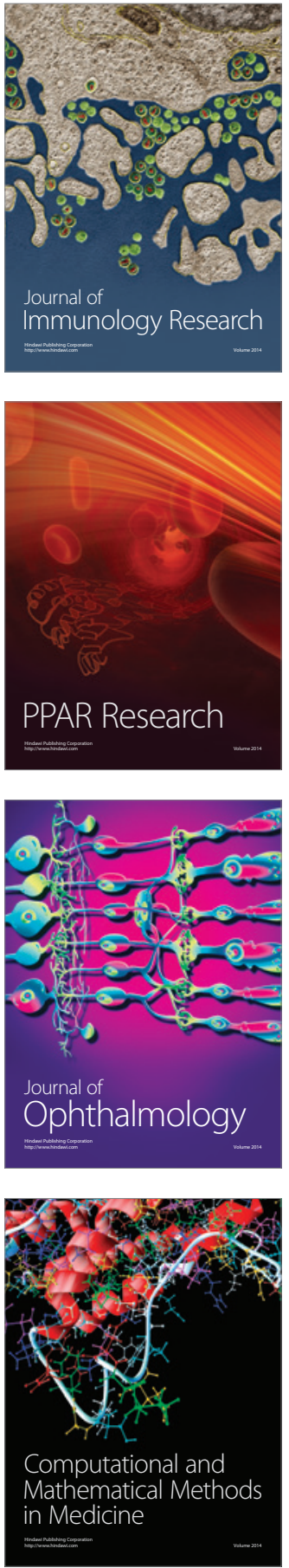

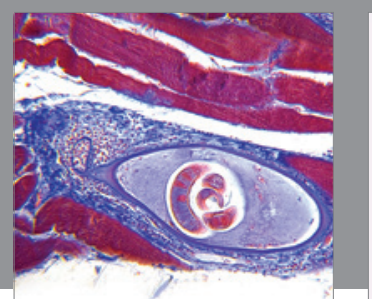

Gastroenterology Research and Practice

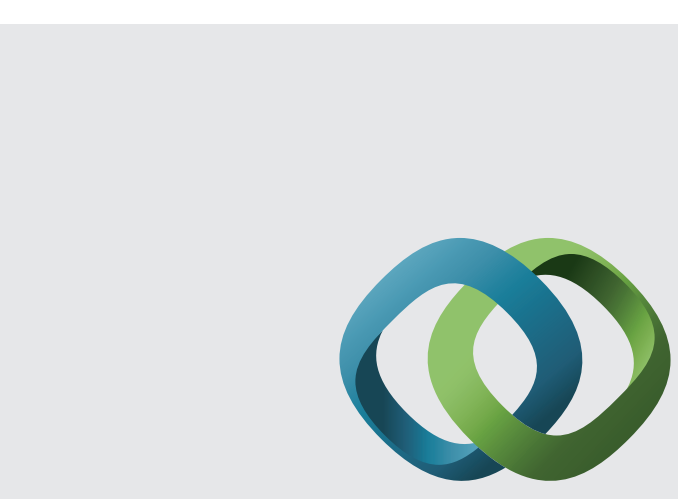

\section{Hindawi}

Submit your manuscripts at

http://www.hindawi.com
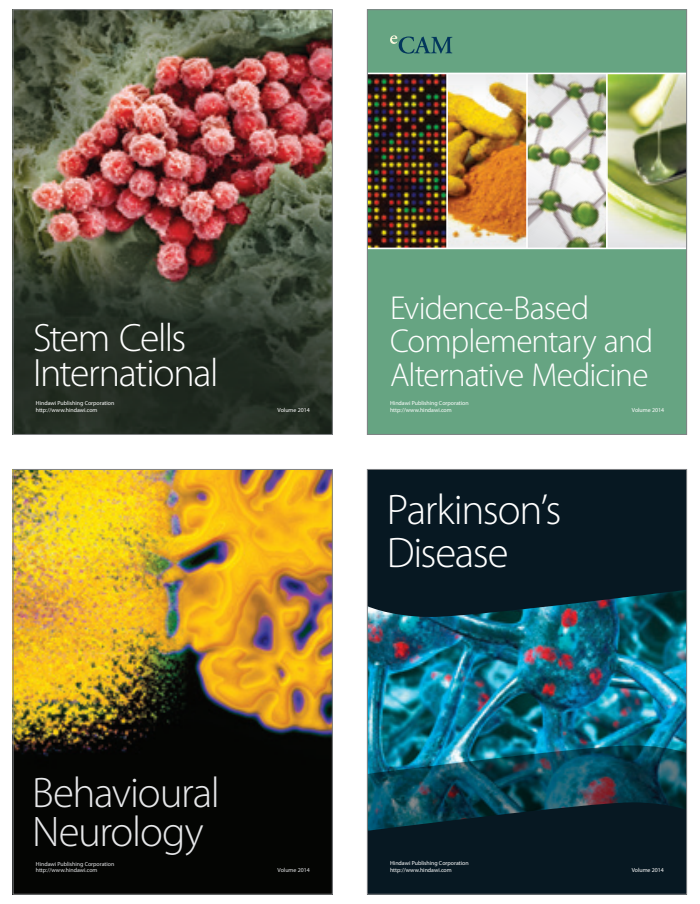
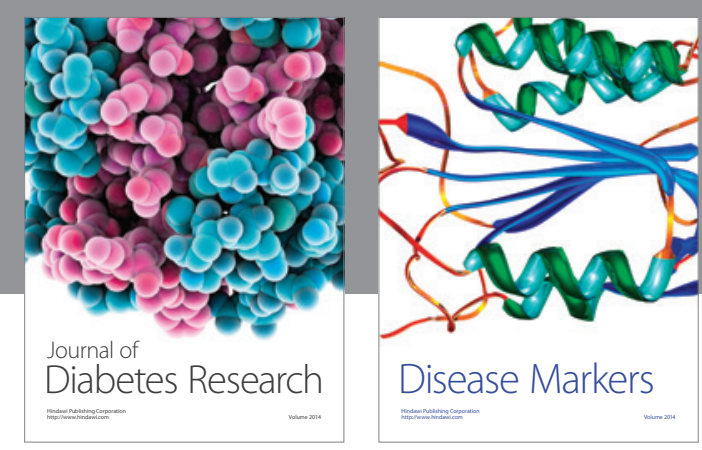

Disease Markers
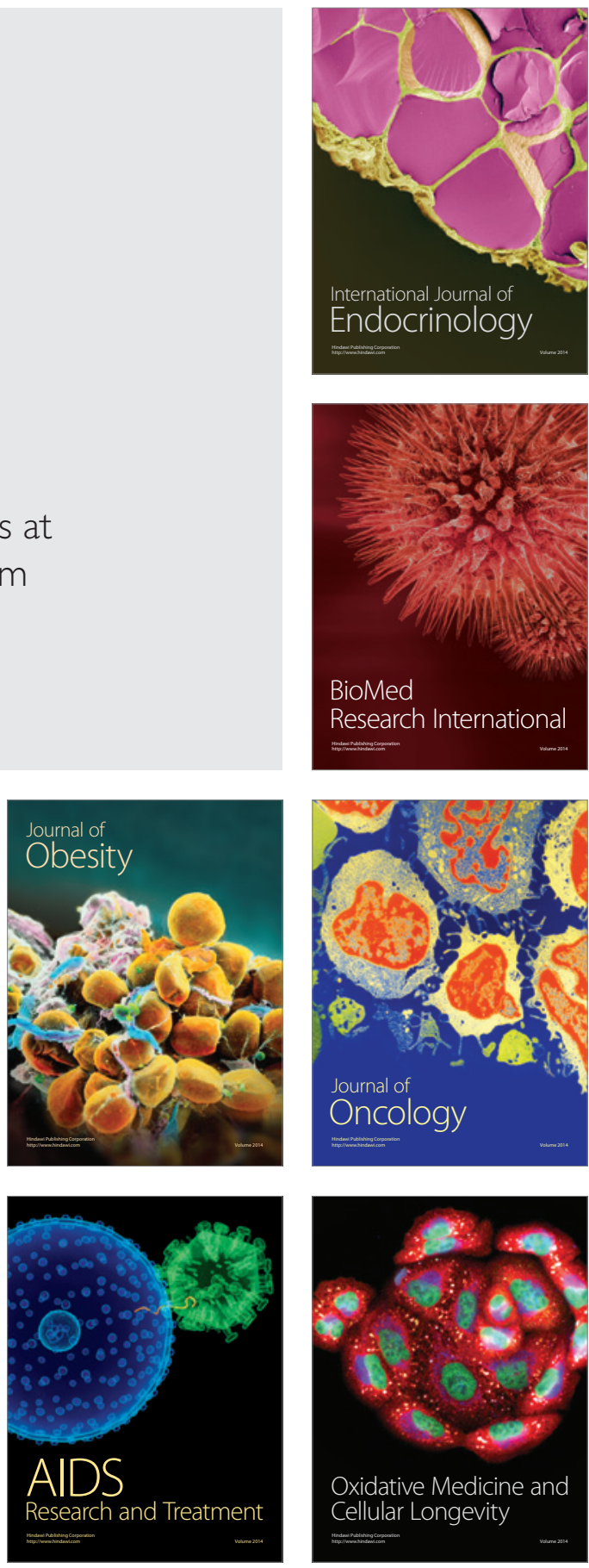